\title{
ВЛИЯНИЕ ИДЕЙ ДЕТЕРМИНИЗМА И ИНДЕТЕРМИНИЗМА НА ФОРМИРОВАНИЕ КОНЦЕПТА СВОБОДЫ ВОЛИ В УГОЛОВНОМ ПРАВЕ
}

\begin{abstract}
Шевелева С.В.
Аннотация: Предмет исследования: В настоящей статье исследуются идеи детерминизма и индетерминизма, которые получили свое развитие в философии, позже в религии, и лишь на рубеже XVIII-XIX вв. нашли свое отражение в философско-юридических исследованиях. Указанные два по сути противоположных направления в подходе к пониманию свободы воли оказали серьезное влияние на формирование основных направлений развития уголовного права: классического, антропологического и сочиологического. На историю российской доктрины повлияли все три отмеченные направления уголовно-правовой мысли, хотя и с разной степенью интенсивности. Предмет исследования: В настоящей статье исследуются идеи детерминизма и индетерминизма, которые получили свое развитие в философии, позже в религии, и лишь на рубеже XVIII-XIX вв. нашли свое отражение в философско-юридчческих исследованиях. Указанные два по сути противоположных направления в подходе к пониманию свободы воли оказали серьезное влияние на формирование основных направлений развития уголовного права: классического, антропологического и сочиологического. На историю российской доктрины повлияли все три отмеченные направления уголовно-правовой мысли, хотя и с разной степенью интенсивности. Научная новизна и выводы: Анализ наиболее ярких исследований в области философии, богословии, политики дало возможность по-новому взглянуть на свободу воли как базовую категорию уголовного права, имеющую свое отражение практически во всех институтах уголовного права. В статье делается вывод, что в современных условиях, следует использовать конструкиию агностицизма, ранее предложенную социологической школой уголовного права: нельзя окончательно разрешить вопрос о том, существует ли свобода воли, однако как допущение можно признать, что она есть, и строить на этой основе уголовное право.
\end{abstract}

Ключевые слова: Свобода воли, детерминизм, индетерминизм, уголовное право, школь уголовного права, Философский подход, абсолютный детерминизм, философия, волевой агностицизм, догматизм.

История вопроса о свободе воли в философской и правовой науке насчитывает не одно тысячелетие. Хронологически в истории рассматриваемого вопроса можно выделять три периода: 1) философский (до начала I тыс. н.э.; точнее, до разработки проблемы свободы воли в патристике); 2) философско-теологический (до рубежа XVIIIXIX вв.); 3) философско-юридический (с рубежа XVIII-XIX вв.). При этом в течение первых двух периодов обсуждение проблемы свободы воли шло преимущественно вне правового контекста; юристы подключились к этой дискуссии позднее, сформулировав несколько подходов к решению обозначенной проблемы. В рамках данного исследования попытаемся выделить наиболее яркие идеи, иллюстрирующие общую тенденцию развития вопроса в конкретный период времени. В силу того, что в конечном итоге нас интересует свобода воли с юридических позиций, а точнее ее отражение в уголовном праве, развитие идеи свободы воли 
в философии и религии рассмотрим схематично путем перехода от одного обозначенного периода к следующему.

Философский подход характеризуется обращением к свободе воли в трудах великих мыслителей Древней Греции и Древнего Рима.

Сократ (470/469-399 гг. до н.э.) одним из первых обратился к понятию свободы, связав её с господством души над телом; истинно свободен тот, кто знает, как управлять своими инстинктами [1] .

В развитие сократовских идей Платон (428/427-347 гг. до н.э.) связал судьбу души со свободно осуществляемым ею выбором. Проходя цикл реинкарнаций, душа вновь и вновь выбирает жить по справедливости и во благе или жить в пороке и зле. При этом правильный выбор зависит от понимания душой сути благой жизни и жизни порочной, от знания, т.е. в платоновском понимании - от философии.

Аристотель (384/383-322 гг. до н.э.) продолжил исследование свободы воли. Идея философа по данному вопросу заключается в том, что все человеческие поступки свободны как хорошие, так и дурные, поэтому Аристотель может рассматриваться как провозвестник будущего индетерминизма; его взгляды на человека и его деятельность (этические взгляды в широком смысле слова) оказали сильное влияние на римскую философию, откуда уже были восприняты латинской патристикой, став тем самым фундаментом западноевропейской философии.

На этом пути необходимо упомянуть Цицерона (106-43 гг. до н.э.). «Он был своего рода мостом, соединившим греческую культуру с римской, а затем с западной в целом» [2] . В цицероновском понимании человек как живое существо соглашается на свои действия: «...Где же тогда добродетель, если от нас ничего не зависит?» («Учение академиков», II 38) [3] .

Одновременно с этим оформляется идея детерминизма человеческих поступков в философии античной Стои (конец IV - III вв. до н.э.). Человек свободен лишь постольку, поскольку понимает веления судьбы и согласует свою жизнь с ними, т.е. «хотящего судьба ведёт, нехотящего - тащит») [4] .

Закатом античного понимания свободы воли стало учение Плотина (204/205-270 гг.), связавшего свободу воли с разумением («...свобода принадлежит воле, насколько воля совпадает с разумом - с разумом, прибавим, правым, то есть обладающим правильным знанием...» («Эннеады», VI.8, 3)).

Философско-теологический подход в истории концепции свободы воли связан с доминированием в научной мысли учений, так или иначе связанных с христианством, к середине I тыс. н.э. ставшим доминирующей религией на территории Европы.

Со свободой воли тесно связаны две (иногда объединяемые) проблемы христианской доктрины. Первая, названная Готфридом Вильгельмом Лейбницем «великим вопросом о свободе и необходимости» [5], связана с происхождением зла в мире (так называемая проблема теодицеи). Кратко её суть выражается в вопросе: если Бог всемогущ, то как он допускает существование в мире зла? Вторая - это проблема Божественного предопределения или, более широко, абсолютного предвидения будущего Богом, исключающего, на первый взгляд, свободу. К их разрешению обратились уже христианские мыслители восточной и западной патристики (IV-V вв.).

Краткий экскурс в историю развития философско-теологического подхода концепции свободы воли показывает соотношение внутренней свободы человека по отношению к воле Бога, которая характеризуется полисемией взглядов современников. Так, учение А. Августина о соотношении свободы воли человека и божественного предопределения является достаточно неоднородным и не носит системного характера, но, в конечном счете, он приходит к выводу, что человек несвободен, он всецело зависит от Бога, т.к. совершив грехопадение, сам выбрал зло и пошёл против воли Бога [6] . Впоследствии рассуждения С. Боэция, оказавшие сильное влияние на европейскую литературу, также отличаются противоречивостью [7] . С одной стороны все действия человека предопределены Богом, с другой, человек свободен в выборе. Данное противоречие он объясняет тем, что знание Богом будущих действий человека, их предвидение, не является необходимой причиной самих этих действий. Позднее Св. Фома Аквинский фактически впервые в своих трудах пытается доказать, что свобода воли человека не предопределена Богом [8] , в силу того, что человек в отличие от животного обладает интеллектом, а, следовательно, возможностью определять свои поступки самостоятельно. Бог, допуская совершение зла на Земле, в силах обратить его в добро. Такая позиция была удобна средневековой церкви, т.к. в этом случае ответственность за поступки возлагались на прихожанина, а не были продиктованы свыше. Рассуждения Э. Роттердамского [9] послужили благодатной почвой для протестантского богословия, при этом он всецело признавал наличие свободы воли. Реформация, родоначальником, 
которой считается М. Лютер, как бы поворачивает все предшествующие рассуждения о свободе воли вспять. Действия человека предопределены Богом, а, следовательно, свобода воли не существует [10] . Такой «откат» продиктован противодействию злоупотреблениям со стороны церкви, в желании последователей М.Лютера показать, что между Богом и человеком существует прямая связь, а наличие церкви с ее традициями излишне. Идеи Ж. Кальвина вообще свелись к абсолютной предопределенности в жизни любого человека, и как следствие полному отсутствию свободы воли и выбора [11] . П. Гольбах, известный своими атеистическими произведениями, также считает поступки людей предопределенными, а наказание для преступников [12] , говоря современным языком, преследует общую превенцию. Католическая церковь Нового Времени, напротив, характеризуется индетерминизскими идеями. При этом в истории XII века достаточно примеров травли за вольнодумство философов и теологов, поддерживавших основные постулаты католической церкви, но обвиненных в ереси (Р. Декарт). Исследования И. Канта можно назвать вершиной индетерминизма, т.к. человека он характеризует тремя способностями: познание, чувство удовольствия и неудовольствия, способность желать .

На основе теологических споров о свободе воле и предопределении в XVII в. с определённостью не только наметились две последующие линии мысли (детерминизм и индетерминизм), но и обозначилось размежевание теологии и философии. Последняя уже не скована жёсткими догматами веры и получает самостоятельное развитие, однако и католический индетерминизм, и протестантский детерминизм стали определяющими на этом пути.

Философско-юридический подход. Начиная с XVIII в. вопрос о свободе воли, оставаясь в философской плоскости, начинает привлекать внимание юристов, и с течением времени происходит размежевание правового и философского представлений о свободе воли: юристы создали на базе сформировавшихся в XVIII-XIX вв. философских построений собственную концепцию свободы воли, тогда как философия продвинулась дальше, в направлении феноменологии, экзистенциализма и других течений.

Исторически первыми к проблеме свободы воли обратились представители классической школы уголовного права, сформировавшейся на базе просветительно-гуманистической школы в конце XVIII - начале XIX вв. [14] Представители последнего направления (Беккариа, Вольтер,
Монтескьё и др.) в основном направляли свой критический взгляд в сторону системы правосудия и карательной системы, сложившейся в Европе в XVIII в., именно классической школе уголовного права принадлежит разработка фундаментальных основ уголовного права и в том числе проблемы свободы воли. У истоков этой школы стояли философские работы Иммануила Канта и Гегеля; её видными представителями в России были А. Ф. Кистяковский, Н. Д. Сергеевский, В. Д. Спасович, Н. С. Таганцев и некоторые другие.

Как отмечает А. В. Наумов, «в наиболее концентрированном виде уголовно-правовые идеи классической школы представлены в творческом наследстве Ансельма Фейербаха..., одного из крупнейших европейских криминалистов XIX века» [15] . Его учебник «Уголовное право» отражает в наиболее концентрированном виде доктрину классической школы [16] .

В интересующем нас вопросе Ансельм Фейербах следующим образом решал проблему свободы воли. Во-первых, она, безусловно, существовала для него постольку, поскольку уголовный закон направляется к общему благу, так как только человек, свободно взвешивающий выгоды от совершения и несовершения преступления, может быть удержан от него [17] .

Во-вторых, ответственности подлежит только тот, кто свободно совершает преступление [18] . В основании преступления при этом лежит побуждение воли, создающее злое намерение (dolus) или неосмотрительность (culpa) [19] .

В-третьих (и отчасти как следствие первых двух моментов) наказанию подлежит только обладающий свободной волей, т.е. вменяемый (в фейербаховском смысле слова) субъект. Обусловлено это тем, что «наказательный закон должен представлением будущего зла действовать на силу желания и оную воздерживать от побуждения к противозаконному делу» [20] . Вменяемость исключалась вследствие случая, детства, необученности глухорождённых и неморождённых, состояния подобных детям стариков, душевной болезни, безвинного чрезмерного упивства, праведного в высочайшей степени неистовствующего душевного движения, безвинного сна или глубокого усыпления, безвинного заблуждения или неведения [21] . Относится к обстоятельствам, исключающим вменяемость, также крайняя необходимость и принуждение: «...Безвинное состояние лица, в котором влияние наказательного закона для воспрепятствования дела или психологически, 
или физически бывает невозможно. Сие случается: 1) когда какое лицо к делу побуждено известным и настоящим злом, наказательному злу по крайней мере равным, и потерю совершенно бесценного и невознаградимого добра в себе заключающим. . .; 2) когда дело единственно по механическим законам (телом)совершено, без всякого к тому побуждения силы желания. К сему надобно причислить и все преступления, какие совершаются посредством действительного насилия (vis absoluta)» [22] .

В-четвёртых, свобода воли допускалась им как обстоятельство, преграждающее наказуемость в случае добровольного отказа от совершения преступления: «...Внешнее деяние, устремлённое с намерением к произведению полного преступления. . . есть уже само по себе нарушение и подлежит наказанию: 1) когда оно не совершено единственно по причине внешних препон, а не по свободной перемене воли...» [23] .

Таким образом, очевидно восприятие Ансельмом Фейербахом концепции индетерминизма; он, по образному выражению А. Принса, «делает её каким-то кормчим, способным вести нас через подводные камни жизни» [24]. Однако такой подход «классика» классической школы не предотвратил появление иных, отличных точек зрения на проблему свободу воли в уголовно-правовом смысле, и российская доктрина уголовного права тому яркий пример.

«Ранняя» литература, следуя традиции классической школы, признавала свободу воли в качестве аксиоматичного положения уголовного права. С чёткостью выражает эту позицию тезис в одной из первых работ по уголовному праву второй половины XIX в.: «Преступная воля имеет своё происхождение в человеческом произволе, или в возможности для человека добра и зла» [25] . В. Д. Спасович писал: «Возможность лица самоопределяться к действию, пока ему служат физические силы, по мере своего знания и творчества, составляет свободу внутреннюю или свободу воли. ...Где нет свободы воли, там нет и свободы действия...» [26] . Для С. Будзинского «преступное деяние есть обнаружение воли; к этому способен только тот, кто имеет свободную волю. ...Свобода, как способность отрешиться от влияния чувственности и подчинить деяния свои идее добра, есть необходимое условие права» [27] ; споры между детерминизмом и индетерминизмом не имеют значения для уголовного права, «для которого вместе со свободою исчезло бы понятие закона и наказания, для которого разумная свобода составляет основание уголовного права» [28] .
По мнению Н. А. Неклюдова, «раз лицо сознаёт самого себя, сознаёт явления внешнего мира и имеет понятие о правах и обязанностях - все условия для ответственности его будут налицо. При наличности таких условий нет надобности вдаваться в вопрос о свободе или несвободе воли» [29]. А. Ф. Кистяковский указывал, что «только то правонарушение считается преступным и наказуемым, которое совершено субъектом по своей воле, словом, с желанием именно его совершить. Это общее начало терпит существенные видоизменения по отношению к преступлениям неосторожным, хотя и здесь оно не теряет всей своей силы» [30] .

Позднее (в том числе под влиянием уголовноантропологического и социологического направлений, о которых речь пойдёт далее) распространение получил близкий к детерминизму взгляд на свободу воли; фактически же в «поздней» науке уголовного права того периода с определённостью так и не была сформулирована господствующая позиция, что, на наш взгляд, может быть объяснено, с одной стороны, общим доминированием философии детерминизма в том период, но, с другой, очевидным для правоведов фактом свободы человека в своём поведении.

Л. С. Белогриц-Котляревский писал, что учение детерминистов ближе к истине, однако это не означает неизбежного фатализма, потому что сознание и воля сохраняют свой контроль за поступками человека: «...Нравственные поступки человека, представляющиеся результатом его нормальных психических сил, не суть нечто стихийнонеизбежное, безусловное; они суть продукты борьбы психических мотивов, на исход которой имеет обыкновенно решающее значение запас полезных для общежития сведений и характер человека, и так как эти последние существенно зависят от самого человека (курсив наш. - С. Ш.), то он и должен подлежать ответственности за свои преступные действия как результат участия психических сил» [31] (позиция во многом индетерминистическая).

Примером абсолютного детерминизма является позиция П. П. Пусторослева: «...Воля человека, наравне со всеми прочими явлениями мира, подчиняется общему закону причинности и под его полновластным господством получает содержание, строго соответствующее сочетанию предшествующих условий, под действием законов природы. Содержание воли представляет собой е продукт её выбора, но последствие, необходимо вытекающее, по закону причинности, из сочетания предшествующих условий под действием законов природы» [32] . 
Обстоятельному анализу проблема свободы воли подвергнута у Н. С. Таганцева [33] . Он признаёт метафизический (философский) характер дискуссии, однако не может избежать её, поскольку решение вопроса влияет не только на вменяемость, но также и на основание уголовной ответственности, оценку принуждения, обоснование наказания и т.д. К индетерминизму Н. С. Таганцев относится критически: его сторонники не могут определить само понятие «свобода», в доказательство своих взглядов ссылаются на ощущения, а не на факты, и т.д. Возражения вызывает и детерминизм, поскольку он устраняет всякую необходимость исследовать вопрос о вменении. Точка зрения самого Н. С. Таганцева получила название «теории закономерности человеческой деятельности»: человеческий поступок, согласно этой теории, имеет место потому, что существует сумма причин и условий, его вызывающих; к одной из таких причин относится и нормальная психическая деятельность лица, совершающего преступление, на которую общество воздействует наказанием. Такая точка зрения, безусловно, близка к детерминизму, поскольку даже нормальная психическая деятельность, по Н. С. Таганцеву, предопределена тем, что окружает человека, и его саморазвитием.

Множество точек зрения в итоге привело к скептицизму уголовно-правовой науки, называвшей споры о свободе воли бесплодными [34]; для В. Д. Спасовича «нет надежды, чтобы когданибудь этот спор прекратился, потому что наше знание имеет свои границы и не в силах решить его окончательно» [35] .

Уголовно-антропологическое (или просто антропологическое) направление возникло во второй половине XIX в. []36 Самыми известными работами, характеризующими эту школу, стали труды Чезаре Ломброзо, выдвинувшего идею о существовании так называемого «преступного человека», отличающегося от «нормального» человека по наследственным и приобретённым органическим и психическим чертам. Ломброзо подробно изучал зависимость преступности от климата, географии, расы, национальности, плотности населения, обеспеченности едой, употребления алкоголя, образования, возраста, экономического состояния, наследственности, семейного положения, профессии, занятости и других факторов. Делаемые им выводы (например, «преступление есть следствие болезненного изменения организма, преимущественно головного или спинного мозга» [37]; «...наследственность... кроется в каком-то тяготении к пороку, сродстве к нему путем подбора, в силу которого преступная женщина выбирает себе в любовники непременно наиболее преступного мужчину...» ) вели к вполне закономерному выводу, согласно которому свободы воли в уголовно-правовом контексте не существует, потому что преступление есть следствие врождённых аномалий. Идея абсолютного детерминизма в совершении преступления прослеживается во всех работах ученого [38] и не оставляют никакого места свободе воли.

Социологическая школа уголовного права (представители этого направления в России - М. Н. Гернет, А. А. Пионтковский (отец), Н. Н. Полянский, И. Я. Фойницкий и др.) рассматривала преступность как социальную аномалию [39] . Разногласия во взглядах социологов иногда были весьма значительны, однако в целом их концепция может быть представлена в следующем виде.

Этой школой была разработана теория факторов преступности, индивидуальных, физических и социальных. Однако главным достижением социологов стало выдвижение теории «опасного состояния личности», смысл которой сводился к тому, что в обществе есть люди, по образу жизни или вследствие своих психических либо физических недостатков опасные для общества. Такую опасность предлагалось устранять средствами уголовного права (через принудительные превентивные меры), в том числе независимо от того, совершил ли такой субъект преступление или нет. Теория «опасного состояния» как объективного факта была неразрывно связана с детерминизмом преступного (опасного) поведения, что, по мнению крайних представителей этой школы, снимает проблему свободы воли.

Как писал Энрико Ферри, «позитивная физиопсихология совершенно уничтожила веру в свободную волю или в нравственную свободу, доказав, что мы должны рассматривать эту свободу исключительно как обман субъективного психологического наблюдения» [40] .

Отрицая свободу воли, социологи задавались вопросом: «...если человек совершает преступление не в силу свободного выбора своей воли, а в силу роковой тирании своего ненормального организма и внешней среды, то по какому праву можно его наказывать, можно считать его ответственным за ошибки, которые не принадлежат ему»? [41] В ответ на это как раз и был выдвинут тезис о мерах социальной защиты как совокупности превентивных и репрессивных социальных мер, 
независящих в своём применении от нравственной вины преступника [42] .

Франц фон-Лист, оказавший сильное влияние на дореволюционную социологическую школу в России, формально не отрицая свободу воли, сводил её, тем не менее, к детерминизму человеческих поступков: «Понятие действия предполагает... произвольное действование лица, осуществление воли. Осуществление же воли есть всякое действование, которое будучи свободным от механического или физиологического принуждения, определено представлениями (детерминировано, мотивировано)» [43] . По его же мнению, «уголовное право не нуждается для своего обоснования в признании беспричинного самоопределения, в принятии свободы воли, изъятой из-под действия закона причинности. Достаточно признать лишь то, что... всякое человеческое действие имеет причинную психическую... связь, т.е. определяется представлениями, детерминировано, мотивировано» [44] .

Более умеренное крыло социологов осторожнее подходило к проблеме свободы воли. По мнению Марка Анселя, «отказ от свободы воли не является сущностью социальной защиты...» [45] . Однако вместо решения проблемы свободы воли он обходит её («...понятия, являющиеся предметом спора, остаются неясными: после нескольких веков борьбы мнений понятие преступной воли, mens rea, столь же неопределённо, как и во времена Цицерона» [46] ), предлагая признать как данность то, что человеку присуще глубокое и естественное чувство личной ответственности, на которое влияет применяемое исправительное воздействие с тем, чтобы воспитать у лица у чувство осознанной свободы [47] . Это своего рода агностицизм в отношении свободной воли, который парадоксально вначале Марком Анселем критикуется [48] . На историю российской доктрины повлияли все три отмеченные направления уголовно-правовой мысли, хотя и с разной степень интенсивности: господство классической школы уголовного права во второй половине XIX - начале XX вв. сопровождалось спорами в основном с представителями социологического направления, хотя и антропологического учения придерживался ряд специалистов.

После октября 1917 г. в теории и практике уголовного права произошёл очевидный поворот, определивший развитие законодательства в последующие десятилетия. Однако поворот этот сопровождался своего рода «метаниями» в решении проблемы свободы воли.

Споры в науке уголовного права привели в 1920 -х гг. к кратковременному периоду господства социологической школы уголовного права. Её следы, отчётливо видные в законодательстве тех лет (Руководящие начала по уголовному праву РСФСР (постановление Наркомюста РСФСР от 12 декабря 1919 г. [49] ); УК РСФСР 1922 г. [50] ; УК РСФСР (редакции 1926 г. [51] )), применительно к вопросу о свободе воли свелись к её отрицанию в русле учения социологов. Например, М. Ю. Козловский, один из авторов Руководящих начал 1919 г., писал: «...Преступник - продукт социальной среды, и ...все его действия, все его побуждения от его и нашей воли не зависят. Нелепо поэтому воздавать ему “должное” за то, в чём он неповинен...» [52] .

Дискуссия по базовым вопросам уголовного права обуславливались, как потом признавали сами её участники, «недостаточной вооружённостью научных работников марксистско-ленинской теорией; тем, что большинство русских дореволюционной представителей уголовно-социологической школы развивали по преимуществу прогрессивные стороны программы этой школы...» [53] . Следует согласиться с А. А. Сулеймановым, который указывает, что «коммунисты-криминалисты того периода не смогли создать принципиально новой социалистической уголовно-правовой доктрины, скомпилировав идеи марксизма с некоторыми положениями основных предшествующих ему теорий. При этом “новизна" сводилась в основном к классовому отличию советского уголовного права от буржуазного... Результатом ...стали политизированность и эклектичность законодательства» [54] .

Начиная с 1930-х гг. в советской доктрине уголовного права начинается развитие учения о свободе воли на базе марксистского понимания этого вопроса, которое, в свою очередь, основывается на идеях Г. В. Ф. Гегеля (1770-1831 гг.). Для Гегеля свобода воли составляет основу психологии духа; объективный дух воплощается в истории через три последовательные ступени: право, мораль и нравственность. Обретение подлинной свободы понимается как предназначение человека, а высшим обнаружением свободы воли становится нравственный поступок [55] . В итоге философия Гегеля сводится к признанию детерминизма человеческих поступков: произвол как основа свободы воли есть иллюзия, поскольку содержание выбора «преднайдено», получается извне [56] .

Марксизм воспринял гегелевскую идею детерминизма, однако развил её в своём направлении. Отталкиваясь от тезиса о том, что бытие определяет сознание, марксисты решали вопрос о свободе воли так, что, с одной стороны, признавали за 
человеком активную роль в общественной жизни, но, с другой, ставили его действия в зависимость от законов материального мира, в том числе права. Краеугольным камнем марксистской философии в этом отношении служил постулат о том, что «свобода воли означает... не что иное, как способность принимать решения со знанием дела» [57] .

В развитие энгельсовских идей В. И. Ленин в одной из своих работ в полемике едко отозвался о свободе воли, не имея ни малейшего представления о том, что это предопределит во многом развитие отечественной мысли на десятилетия: «Идея детерминизма, устанавливая необходимость человеческих поступков, отвергая вздорную побасенку о свободе воли, нимало не уничтожает ни разума, ни совести человека, ни оценки его действий» [58] .

На этой философской основе в советской науке уголовного права была развита так называемая «детерминистская концепция преступного поведения». В соответствии с ней в самом общем виде поведение людей предопределено внешними обстоятельствами, однако, подвергаясь воздействию внешних обстоятельств, человек сохраняет возможность свободно (точнее, условно свободно, поскольку и эта свобода детерминирована) принимать решения, и это обосновывает возможность привлечения его к уголовной ответственности. Доктрина дистанцировалась и от абсолютного индетерминизма, и от абсолютного детерминизма.

По словам А. А. Пионтковского, «марксизм признаёт свободу воли как возможность человека принимать решения со знанием дела. Детерминизм не означает фатализма. Конкретная обстановка, в которой оказывается лицо, не обрекает его фаталистически действовать в определённом направлении. Человек может противостоять непосредственному воздействию конкретной ситуации, в которой он оказывается» [59] .

При этом в связи с неосторожными преступлениями марксистски понимаемая свобода воли остаётся основанием уголовной ответственности постольку, поскольку «у человека была возможность принять решение с пониманием характера своих действий и их последствий, но он, однако, вследствие проявленной невнимательности... совершает общественно опасное деяние...» [60] .

По справедливой оценке А. В. Наумова, признание активной роли лица и свободы в принятии им решения о совершении преступления на деле означала признание двойной детерминированности преступного поведения, с одной стороны, внешними факторами и, с другой, - уровнем сознания субъекта, его нравственными и иными личностными качествами; он «обречён» совершать преступления [61] .

Применительно к уголовному праву развитие идеи «жёсткой» детерминированности можно увидеть у М. Д. Шаргородского. Он, отстаивая идею полного детерминизма, писал, что «ответственность может иметь место только в том случае, когда есть возможность выбора, т.е. когда объективно существует более чем один вариант возможного поведения, и из них субъект выбирает. Нет выбора и выбор детерминирован - это вовсе не одно и то же. Нет выбора - это значит, что воля и разум человека не принимают участия в детерминации конкретного события. Детерминирован же любой совершаемый поступок, любой акт поведения» [62] . Мысль М. Д. Шаргородского такова: пока поступок не совершён, есть разные варианты поведения; однако, будучи совершён, он должен рассматриваться как полностью детерминированный как внешними по отношению к действующему, так и внутренними факторами [63] . Это, по его мнению, допускает существование свободы воли. «...Индетерминистские теории (как и фаталистические) могли... дать только этическое основание ответственности как причинение страдания, возмездия, кары за причинённое страдание, за грех, за содеянное. Детерминизм обосновывает необходимость ответственности, он объясняет, для чего применяется ответственность... Только тогда, когда ответственность (наказание, упрёк, оценка) детерминирует выбор субъектом конкретной формы его поведения, она имеет смысл» [64] .

Следует признать, что в советский период так и не было найдено приемлемого решения проблемы соотношения детерминированности поведения, неизбежности и необходимости преступления.

В рассматриваемый период времени любые попытки отойти от изложенного понимания свободы воли встречали ожесточённую критику в науке с обвинениями в антимарксизме и т.п. Например, Т. Л. Сергеева писала: «Наличие или отсутствие соответствующего психического отношения зависит от самого лица... От самого человека зависит направить свое сознание и волю к той или иной цели, использовать свои психические возможности для той или иной деятельности» [65] . Это положение было критически встречено как допускающее наличие полной свободы воли [66] .

По мнению Б. С. Утевского, основание уголовной ответственности заключается в том, что «гражданин, совершивший преступление, имел возможность выбрать решение, соответствующее интересам социалистического государства, т.е. 
решение свободное, соответствующее законам общественного развития, но вместо этого подчинил свое решение пережиткам капитализма в своем сознании или влиянию капиталистического окружения» [67] . За это утверждение Б. С. Утевский был подвергнут уничтожающей критике как за попытку совместить индетерминизм («решение свободное...») и фатализм («пережитки капитализма...») [68] .

Однако позднее догматизм марксизма начал постепенно ослабляться. В качестве примера можно сослаться на позицию А. М. Яковлева, который писал: «Исходный принцип уголовного права - представление о противоправном деянии как об акте воли лица, способного руководить своими действиями... Для уголовного права преступление - результат собственного выбора лицом противоправного варианта поведения в условиях, когда такой выбор был объективно возможен. ... Вся концепция уголовно-правовой ответственности базируется на понимании преступления как результата свободно принятого решения» [69] . Напротив, «для криминологии, занимающейся выявлением причин совершения преступлений, важно обнаружить закономерности, объективно и неизбежно вызывающие к жизни преступления определенных видов» [70] .
По мнению П. С. Дагеля, хотя воля человека и детерминирована окружающими условиями, внешней средой, а также личностью самого человека, её свобода не может отрицаться, поскольку это означает отрицание вины и ответственности [71] .

Вместе с тем вплоть до конца 1980-х гг. детерминизм занимал (как минимум, формально) господствующее положение в уголовном праве и криминологии.

Обобщая историю вопроса о свободе воли в философии и доктрине уголовного права, можно говорить о существовании двух основных направлений мысли: детерминизма и индетерминизма; к ним в XX в. прибавился «волевой агностицизм». Два обозначенных первыми направления могут быть также разделены на абсолютное и относительное; крайними точками зрения, соответственно, будут абсолютные детерминизм и индетерминизм; промежуточными - относительные детерминизм и индетерминизм. В борьбе этих направлений развивались философия и уголовное право на протяжении всей их истории, и во многом борьба эта не окончена и сегодня.

Таким было неоднозначное и сложное развитие проблемы свободы воли в философии и уголовном праве, на основе которого можно совершать попытки построения современной уголовно-правовой концепции свободы воли.

\section{Библиография:}

1. Августин // Католическая энциклопедия. В 4 т. Т. 1: А-3. - М., 2002.

2. Ансель Марк. Новая социальная защита (гуманистическое движение в уголовной политике) / пер. с фр. Н. С. Лапшиной; под ред. и со вступ. ст. А. А. Пионтковского. - М., 1970.

3. Белогриц-Котляревский Л. С. Учебник русского уголовного права. Общая и Особенная части. Киев; Пб. - Харьков, 1904.

4. Будзинский С. Начала уголовного права. - Варшава, 1870.

5. Власьев П. О вменении по началам теории и древнего русского права. - М., 1860.

6. Гегель. Философия права. - М., 1990.

7. Гольбах Поль Анри. Система природы, или о законах мира физического и мира духовного // Гольбах Поль Анри. Избранные произведения. В 2 т. Т. 1 / пер с фр. П. С. Юшкевича; под общ. ред. и со вступ. ст. Х. Н. Момджяна. - М., 1963.

8. Дагель П. С., Котов Д. П. Субъективная сторона преступления // Дагель П. С. Избранные труды / науч. ред. и предисл. А. И. Коробеева. Владивосток, 2009.

9. Кальвин Жан. Наставления в христианской вере / пер. с фр. А. Д. Бакулова, науч. ред. Ю. А. Кимелев. - М., 1996.

10. Кант И. Критическое освещение аналитики чистого практического разума // Кант И. Собрание сочинений. В 8 т. Т. 4. - М., 1994.

11. Кистяковский А. Ф. Элементарный учебник общего уголовного права. Т. 1: Общая часть. - Киев, 1875.

12. Козловский М. Ю. Пролетарская революция и уголовное право // Пролетарская революция и право. 1918. № 1.

13. Курс советского уголовного права / редкол. А. А. Пионтковский и др. В 6 т. Т. ІІ: Преступление. M., 1970. 
14. Курс советского уголовного права / редкол. А. А. Пионтковский и др. В 6 т. Т. І: Уголовный закон. - М., 1970.

15. Лейбниц Г. В. Опыты теодицеи о благости Божией, свободе человека и начале зла // Лейбниц Г. В. Сочинения. В 4 т. Т. 4. - М., 1989.

16. Ленин В. И. Что такое «друзья народа» и как они воюют против социал-демократов? // Ленин В. И. Полное собрание сочинений. 5-е изд. Т. 1. - М., 1967.

17. Ломброзо С. Новейшие успехи науки о преступнике / пер.: Раппопорт С.Л. / под ред. и с пред.: Берлин Л.М. - С. - Пб.: Н.К. Мартынов, 1892.

18. Ломброзо С., Ферреро Г.; Женщина преступница и проститутка / Пер.: Гордон Г.И. - Харьков, Киев: Ф.А. Иогансон, 1897.

19. Ломброзо Ч. Гениальность и помешательство. Репринтное воспроизведение издания Ф. Павленкова. «С. - Петербург», 1982 г. / пер.: Тетюшинова К. - М.: Изд-во ТПО ТАМП Междунар. Центра Михаила Чехова, 1990.

20. Ломброзо Ч. Преступление /-М.: Спарк, 1994.

21. Ломброзо Ч. Преступный человек / пер. с ит. - М.; СПб., 2005.

22. Ломброзо Ч., Ляски Р. Политическая преступность и революция по отношению к праву, уголовной антропологии и государственной науке / пер.: Толстой К.К. - С. - Пб.: Ред. «Нового журн. лит., искусства и науки» (Ф. И. Булгакова), 1906.

23. Марк Туллий Цицерон. Учение академиков / пер. Н. А. Фёдорова; коммент. и вступ. ст. М. М. Сокольской. М., 2004.

24. Наумов А. В. Российское уголовное право. Курс лекций. Т. 1. - М.: Волтерс Клувер, 2011.

25. Неклюдов Н. А. Общая часть уголовного права (конспект). СПб., 1875.

26. Новгородцев П. И. Кант и Гегель в их учениях о праве и государстве. - СПб., 2000.

27. Пионтковский А. А. Учение Гегеля о праве и государстве и его уголовно-правовая теория. - М., 1993.

28. Принс Ад. Защита общества и преобразование уголовного права / пер. с фр. Е. Маркеловой; под ред. и с предисл. Г. С. Фельдштейна. - М., 1912.

29. Пусторослев П. П. Преступность, виновность и вменяемость // Журнал Министерства юстиции. 1907. № 4. Апрель.

30. Реале Дж., Антисери Д. Западная философия: от истоков до наших дней / пер. с ит. Т. 1: Античность. - СПб., 1994.

31. Реале Дж., Антисери Д. Западная философия: от истоков до наших дней / пер. с ит. Т. 4: От романтизма до наших дней. - СПб., 1997.

32. Решетников Ф. М. Уголовное право буржуазных стран. Вып. 2: «Классическая» школа и антрополого-социологическое направление. - М., 1966.

33. Сергеева Т. Л. Вопросы виновности и вины в практике Верховного суда СССР по уголовным делам. М.;-Л., 1950.

34. Спасович В. Учебник уголовного права. Т. І. - СПб., 1863.

35. СУ РСФСР. 1919. № 15. Ст. 153.

36. СУ РСФСР. 1919. № 66. Ст. 590.

37. СУ РСФСР. 1926. № 80. Ст. 600.

38. Сулейманов А. А. Первый Уголовный кодекс РСФСР: концептуальные основы и общая характеристика. - Владимир, 2006.

39. Таганцев Н. С. Русское уголовное право. Часть общая. В 2 т. Т. 1. Тула, 2001.

40. Уголовное право. Сочинение доктора Павла Анзельма Фейербаха. - СПб., 1810.

41. Утевский Б. С. Вина в советском уголовном праве. - М., 1950.

42. Ферри Э. Уголовная социология / сост. и предисл. В. С. Овчинского. - М., 2005.

43. Фома Аквинский. Сумма теологии / пер., ред. и примеч. С. И. Еремеева. Часть 1: Вопросы 75-119. - Киев, 2005.

44. Франц фон-Лист. Учебник уголовного права. Общая часть / предисл. автора и М. В. Духовского. M., 1903.

45. Шаргородский М. Д. Детерминизм и ответственность // Шаргородский М. Д. Избранные работы по уголовному праву / сост. и предисл. Б. В. Волженкина. - СПб., 2003.

46. Эдельгауз Е. М. К вопросу о понятии свободы воли в уголовном праве // Правоведение. 1962. № 4. 
47. Энгельс Ф. Анти-Дюринг // Маркс К., Энгельс Ф. Сочинения. 2-е изд. Т. 20. - М., 1961.

48. Эразм Роттердамский. Диатриба, или рассуждение о свободе воли // Эразм Роттердамский. Философские произведения / отв. ред. В. В. Соколов, пер. и комм. Ю. М. Каган. - М., 1986.

49. Яковлев А. М. Детерминизм и «свобода воли»: перспективы изучения личности преступника // Правоведение. 1976. № 6.

\section{References (transliterated):}

1. Avgustin // Katolicheskaya entsiklopediya. V 4 t. T. 1: A-Z. - M., 2002.

2. Ansel' Mark. Novaya sotsial'naya zashchita (gumanisticheskoe dvizhenie v ugolovnoi politike) / per. s fr. N. S. Lapshinoi; pod red. i so vstup. st. A. A. Piontkovskogo. - M., 1970.

3. Belogrits-Kotlyarevskii L. S. Uchebnik russkogo ugolovnogo prava. Obshchaya i Osobennaya chasti. Kiev; Pb. - Khar'kov, 1904.

4. Budzinskii S. Nachala ugolovnogo prava. - Varshava, 1870.

5. Vlas'ev P. O vmenenii po nachalam teorii i drevnego russkogo prava. - M., 1860.

6. Gegel'. Filosofiya prava. - M., 1990.

7. Gol'bakh Pol' Anri. Sistema prirody, ili o zakonakh mira fizicheskogo i mira dukhovnogo // Gol'bakh Pol' Anri. Izbrannye proizvedeniya. V 2 t. T. 1 / per s fr. P. S. Yushkevicha; pod obshch. red. i so vstup. st. Kh. N. Momdzhyana. - M., 1963.

8. Dagel' P. S., Kotov D. P. Sub"ektivnaya storona prestupleniya // Dagel' P. S. Izbrannye trudy / nauch. red. i predisl. A. I. Korobeeva. Vladivostok, 2009.

9. Kal'vin Zhan. Nastavleniya v khristianskoi vere / per. s fr. A. D. Bakulova, nauch. red. Yu. A. Kimelev. M., 1996.

10. Kant I. Kriticheskoe osveshchenie analitiki chistogo prakticheskogo razuma // Kant I. Sobranie sochinenii. V 8 t. T. 4. - M., 1994.

11. Kistyakovskii A. F. Elementarnyi uchebnik obshchego ugolovnogo prava. T. 1: Obshchaya chast'. - Kiev, 1875.

12. Kozlovskii M. Yu. Proletarskaya revolyutsiya i ugolovnoe pravo // Proletarskaya revolyutsiya i pravo. 1918. № 1.

13. Kurs sovetskogo ugolovnogo prava / redkol. A. A. Piontkovskii i dr. V 6 t. T. II: Prestuplenie. - M., 1970.

14. Kurs sovetskogo ugolovnogo prava / redkol. A. A. Piontkovskii i dr. V 6 t. T. I: Ugolovnyi zakon. - M., 1970.

15. Leibnits G. V. Opyty teoditsei o blagosti Bozhiei, svobode cheloveka i nachale zla // Leibnits G. V. Sochineniya. V 4 t. T. 4. - M., 1989.

16. Lenin V. I. Chto takoe «druz'ya naroda» i kak oni voyuyut protiv sotsial-demokratov? // Lenin V. I. Polnoe sobranie sochinenii. 5-e izd. T. 1. - M., 1967.

17. Lombrozo S. Noveishie uspekhi nauki o prestupnike / per.: Rappoport S.L. / pod red. i s pred.: Berlin L.M. - S. - Pb.: N.K. Martynov, 1892.

18. Lombrozo S., Ferrero G.; Zhenshchina prestupnitsa i prostitutka / Per.: Gordon G.I. - Khar'kov, Kiev: F.A. Ioganson, 1897.

19. Lombrozo Ch. Genial'nost' i pomeshatel'stvo. Reprintnoe vosproizvedenie izdaniya F. Pavlenkova. "S. Peterburg", 1982 g. / per.: Tetyushinova K. - M.: Izd-vo TPO TAMP Mezhdunar. Tsentra Mikhaila Chekhova, 1990.

20. Lombrozo Ch. Prestuplenie /-M.: Spark, 1994.

21. Lombrozo Ch. Prestupnyi chelovek / per. s it. - M.; SPb., 2005.

22. Lombrozo Ch., Lyaski R. Politicheskaya prestupnost' i revolyutsiya po otnosheniyu k pravu, ugolovnoi antropologii i gosudarstvennoi nauke / per.: Tolstoi K.K. - S. - Pb.: Red. "Novogo zhurn. lit., iskusstva i nauki” (F. I. Bulgakova), 1906.

23. Mark Tullii Tsitseron. Uchenie akademikov/per. N. A. Fedorova; komment. i vstup. st. M. M. Sokol'skoi. M., 2004.

24. Naumov A. V. Rossiiskoe ugolovnoe pravo. Kurs lektsii. T. 1. - M.: Volters Kluver, 2011.

25. Neklyudov N. A. Obshchaya chast' ugolovnogo prava (konspekt). SPb., 1875.

26. Novgorodtsev P. I. Kant i Gegel' v ikh ucheniyakh o prave i gosudarstve. - SPb., 2000.

27. Piontkovskii A. A. Uchenie Gegelya o prave i gosudarstve i ego ugolovno-pravovaya teoriya. - M., 1993. 
28. Prins Ad. Zashchita obshchestva i preobrazovanie ugolovnogo prava / per. s fr. E. Markelovoi; pod red. i s predisl. G. S. Fel'dshteina. - M., 1912.

29. Pustoroslev P. P. Prestupnost', vinovnost' i vmenyaemost'// Zhurnal Ministerstva yustitsii. 1907. № 4. Aprel'.

30. Reale Dzh., Antiseri D. Zapadnaya filosofiya: ot istokov do nashikh dnei / per. s it. T. 1: Antichnost'. - SPb., 1994.

31. Reale Dzh., Antiseri D. Zapadnaya filosofiya: ot istokov do nashikh dnei / per. s it. T. 4: Ot romantizma do nashikh dnei. - SPb., 1997.

32. Reshetnikov F. M. Ugolovnoe pravo burzhuaznykh stran. Vyp. 2: «Klassicheskaya» shkola i antropologosotsiologicheskoe napravlenie. - M., 1966.

33. Sergeeva T. L. Voprosy vinovnosti i viny v praktike Verkhovnogo suda SSSR po ugolovnym delam. M.;-L., 1950.

34. Spasovich V. Uchebnik ugolovnogo prava. T. I. - SPb., 1863.

35. SU RSFSR. 1919. № 15. St. 153.

36. SU RSFSR. 1919. № 66. St. 590.

37. SU RSFSR. 1926. № 80. St. 600.

38. Suleimanov A. A. Pervyi Ugolovnyi kodeks RSFSR: kontseptual'nye osnovy i obshchaya kharakteristika. - Vladimir, 2006.

39. Tagantsev N. S. Russkoe ugolovnoe pravo. Chast' obshchaya. V 2 t. T. 1. Tula, 2001.

40. Ugolovnoe pravo. Sochinenie doktora Pavla Anzel'ma Feierbakha. - SPb., 1810.

41. Utevskii B. S. Vina v sovetskom ugolovnom prave. - M., 1950.

42. Ferri E. Ugolovnaya sotsiologiya / sost. i predisl. V. S. Ovchinskogo. - M., 2005.

43. Foma Akvinskii. Summa teologii / per., red. i primech. S. I. Eremeeva. Chast' 1: Voprosy 75-119. - Kiev, 2005.

44. Frants fon-List. Uchebnik ugolovnogo prava. Obshchaya chast' / predisl. avtora i M. V. Dukhovskogo. - M., 1903.

45. Shargorodskii M. D. Determinizm i otvetstvennost'// Shargorodskii M. D. Izbrannye raboty po ugolovnomu pravu / sost. i predisl. B. V. Volzhenkina. - SPb., 2003.

46. Edel'gauz E. M. K voprosu o ponyatii svobody voli v ugolovnom prave // Pravovedenie. 1962. № 4.

47. Engel's F. Anti-Dyuring // Marks K., Engel's F. Sochineniya. 2-e izd. T. 20. - M., 1961.

48. Erazm Rotterdamskii. Diatriba, ili rassuzhdenie o svobode voli // Erazm Rotterdamskii. Filosofskie proizvedeniya / otv. red. V. V. Sokolov, per. i komm. Yu. M. Kagan. - M., 1986.

49. Yakovlev A. M. Determinizm i «svoboda voli»: perspektivy izucheniya lichnosti prestupnika // Pravovedenie. 1976. № 6 . 